\title{
Effect of Pasteurization Temperature, Starter Culture, and Incubation Temperature on the Physicochemical Properties, Yield, Rheology, and Sensory Characteristics of Spreadable Goat Cheese
}

\author{
Florencia Frau, ${ }^{1}$ Graciela Font de Valdez, ${ }^{2}$ and Nora Pece ${ }^{1}$ \\ ${ }^{1}$ Instituto de Ciencia y Tecnología de Alimentos, Facultad de Agronomía y Agroindustrias, Universidad Nacional de Santiago del Estero, \\ Avenida Belgrano (S) 1912, 4200 Santiago del Estero, Argentina \\ ${ }^{2}$ CERELA, CONICET, Chacabuco 145, 4000 San Miguel de Tucumán, Argentina
}

Correspondence should be addressed to Florencia Frau; ffrau@unse.edu.ar

Received 14 May 2014; Revised 8 September 2014; Accepted 10 September 2014; Published 2 October 2014

Academic Editor: Vassiliki Oreopoulou

Copyright (C) 2014 Florencia Frau et al. This is an open access article distributed under the Creative Commons Attribution License, which permits unrestricted use, distribution, and reproduction in any medium, provided the original work is properly cited.

\begin{abstract}
The local cheese factories currently use bovine commercial starter cultures, and the spreadable cheese process is not standardized. A detailed understanding of the effect of pasteurization temperature, starter culture, and incubation temperature must allow producers to optimize the process, increase cheese yield, and improve the quality of the final product. The main objective of the study was to describe the preparation method of spreadable goat cheese and investigate the effects of specific processing conditions (pasteurization temperature, starter culture, and incubation temperature) on the composition, yield, rheology, and sensory characteristics of the final product. Results showed the impact of pasteurization temperature, starter culture, and incubation temperature on spreadable goat cheese. The results indicated that it is possible to improve cheese yield, rheological properties, and sensory analysis when milk is pasteurized at $75^{\circ} \mathrm{C}$ for 30 minutes; cheese yield can also be improved by lowering incubation temperature to $37^{\circ} \mathrm{C}$. Cheeses made with autochthonous starter culture showed better sensory characteristics and higher $\mathrm{pH}$ compared to the cheeses made with commercial culture.
\end{abstract}

\section{Introduction}

Fresh acid-curd cheeses refer to those varieties produced by the coagulation of milk, cream, or whey via acidification and those which are ready for consumption once the manufacturing operations are complete. They differ from rennetcurd cheese variety in that coagulation occurs close to the isoelectric point of casein; a very small amount of rennet may be used in the production of quarg, cottage, or spreadable cheese [1].

The production of spreadable cheese generally involves milk pretreatments, slow acidification and gelation, whey separation, and/or curd treatment. Many processing conditions influence coagulum structure and hence the rheological and physicochemical stability of the product [1]. In recent years, the manufacture of various cheese varieties has received considerable interest, mainly because of the potential to improve cheese yield, through incorporation of whey proteins into cheese curd. There are only a few studies in spreadable cheese and fewer in spreadable goat cheese [2].

However, the cheese-making characteristics of heated milks $\left(>65^{\circ} \mathrm{C}\right)$ differ markedly from those of typically pasteurized milk $\left(63-65^{\circ} \mathrm{C}\right)$. Milk that has been heat-treated at higher temperatures shows longer coagulation times and forms weaker and finer curd which retains more water. These effects are considered to arise mainly from the formation of complexes between denatured whey proteins and micellar $\kappa$ casein, which subsequently modifies the surface characteristics and interactions of casein micelles $[3,4]$.

Goat milk microflora is essential for the manufacture of cheeses, conferring on them particular and distinctive flavor and generating high value-added products. 
Usually commercial starters, selected for cow milk, are added in the manufacture and cheeses obtained have variable quality and little characteristic flavor.

The use of autochthonous cultures is not widespread yet;; therefore it is essential to study the effect of autochthonous starter culture in spreadable goat cheese. Because of the growing interest in preserving the typical sensory properties of traditional cheeses, there is an increasing demand for autochthonous strains to replace or complement existing commercial starters currently used by the dairy industry $[5,6]$.

However, there are not studies about autochthonous starter culture for spreadable goat cheese. This study is necessary since the elaboration and sensory attributes of this variety are different from enzymatic coagulation cheese.

Gel formation is the most important functional property of fermented milk products. The rheological characteristics of this composite gel are governed by milk composition, dry matter content, type and quantity of the starter culture that is used to inoculate the milk, fermentation temperature, and storage conditions of the final product $[7,8]$.

There is an increasing demand for new products in the food market. Hedonic scales and preference tests are common instruments used when decisions on market introductions are made. Sensory analyses are also used for quality control, for the comparison of product prototypes to understand consumer responses in relation to products' sensory attributes, and for sensory mapping and product matching. It may also be used to track product changes over time with respect to understanding shelf life and packaging effects, to investigate the effects of ingredients or processing variables on the final sensory quality of a product and to investigate consumer perceptions of products [9].

The aim of this work was to investigate the effects of specific processing conditions (pasteurization temperature, starter culture, and incubation temperature) on the physicochemical properties, yield, rheology, and sensory characteristics of the spreadable goat cheese and to describe an improved elaboration process.

\section{Materials and Methods}

2.1. Materials. Bulk goat milk from the morning milking was obtained from a local farm. Two vats of cheese were made on the same day at the pilot plant of the University of Santiago del Estero from June to December. Two elaborations were performed per month and the results presented are the mean values.

The autochthonous starter culture used in this study was isolated in the Laboratory of Centro de Referencia para Lactobacilos (CERELA, Tucumán, Argentina) from goat cheeses elaborated in Santiago del Estero. Four strains constituted the autochthonous culture: CRL 1799 (Lactobacillus fermentum with high acidifying activity), CRL 1803 (Lactobacillus fermentum with high proteolytic activity), CRL 1785 (Enterococcus faecium with diacetyl-acetoin production), and CRL 1808 (Lactobacillus rhamnosus exopolysaccharide producing strain) in the ratio $1: 1: 1: 3$. The criteria for selection of these strains and development of autochthonous starter culture for spreadable goat's milk cheese are explained in [2].

Freeze dried bovine commercial culture (Diagrama SLB 95) was purchased from Diagrama (Santa Fé, Argentina).

\subsection{Methods}

2.2.1. Preparation of the Autochthonous Working Culture. The working culture was prepared according to the method described in [2].

\subsubsection{Spreadable Cheese Processing}

(1) Effect of Pasteurization Temperature. Two vats of cheese (three liters each) were made on one day from fresh goat milk obtained from a local farm. For each batch, milk was pasteurized for 30 minutes at two different temperatures (65 and $75^{\circ} \mathrm{C}$ ) and then was cooled to $37^{\circ} \mathrm{C}$ and $0.035 \mathrm{~g} / \mathrm{L} \mathrm{of} \mathrm{CaCl}_{2}$ was added. After that, milk was inoculated with $1 \mathrm{~mL} / 100 \mathrm{~mL}$ autochthonous goat culture $\left(10^{7} \mathrm{CFU} / \mathrm{mL}\right)$. Samples were finally fermented in a thermostatically controlled incubator at $37^{\circ} \mathrm{C}$. When $\mathrm{pH} \leq 6.2$ bovine curdle was added $(20 \%$ of the quantity needed for enzymatic coagulation) and incubated at $37^{\circ} \mathrm{C}$ for 1 hour. After this procedure cheese curds were salted ( $1.5 \% \mathrm{w} / \mathrm{w}$ of the milk weight) and drained off in cheese cloth at $30^{\circ} \mathrm{C}$ overnight until $\mathrm{pH} \leq 5.3$. The cheese obtained was vacuum packaged using polyethylene bags $(100 \mu \mathrm{m})$ and matured at $7^{\circ} \mathrm{C}$ for 5 days.

(2) Effect of Starter Culture. Milk was pasteurized at $75^{\circ} \mathrm{C}$ and cooled and $\mathrm{CaCl}_{2}$ was added. Milk was divided into two batches and inoculated $(1 \mathrm{~mL} / 100 \mathrm{~mL})$ : one with autochthonous goat culture $\left(10^{7} \mathrm{CFU} / \mathrm{mL}\right)$ and the other with bovine commercial starter culture $\left(10^{7} \mathrm{CFU} / \mathrm{mL}\right)$. Elaboration proceeded as described in (1).

(3) Effect of Incubation Temperature. Milk was pasteurized and cooled; $\mathrm{CaCl}_{2}$ added and inoculated as previously described in (2). After these procedures, milk was divided into two batches. Fermentation was carried out at different temperatures $\left(37\right.$ and $42^{\circ} \mathrm{C}$ ). Elaboration proceeded as described in (1).

2.2.3. Milk and Cheese Chemical Composition. Samples of goat milk were analyzed for fat, protein, lactose, and nonfat solids using LactoStar Funke Gerber 3560.

Cheese samples were analyzed for fat [10], protein [11], total solids content [12], and ash [13]. Moisture content was determined by

$$
\text { Moisture (\%) = } 100-\text { Total solids (\%). }
$$

2.2.4. $\mathrm{pH}$ Determination. Milk $\mathrm{pH}$ was determined using a Hanna model HI $98240 \mathrm{pH}$-meter. The $\mathrm{pH}$ value of the cheeses was measured at the end of maturation and shelf life.

The $\mathrm{pH}$ electrode was inserted directly into the sample and the $\mathrm{pH}$ reading taken when the value had stabilized (typically $<5 \mathrm{~min}$ ). Each sample was measured in duplicate. 
TABLE 1: Chemical composition of spreadable goat cheese, milk, and whey.

\begin{tabular}{|c|c|c|c|c|}
\hline \multirow{2}{*}{ Component } & \multicolumn{2}{|c|}{ Cheese } & \multirow{2}{*}{ Whey } & \multirow{2}{*}{ Milk } \\
\hline & $65^{\circ} \mathrm{C}$ & $75^{\circ} \mathrm{C}$ & & \\
\hline Fat (\%) & $23.5 \pm 2.35$ & $22.42 \pm 2.62$ & $0.11 \pm 0.01$ & $5.52 \pm 1.00$ \\
\hline Protein (\%) & $22.75 \pm 1.02$ & $20.79 \pm 1.03$ & $1.47 \pm 0.01$ & $3.40 \pm 0.22$ \\
\hline Casein (\%) & $16.82 \pm 0.31$ & $14.13 \pm 0.35$ & $0.42 \pm 0.06$ & $2.17 \pm 0.40$ \\
\hline Lactose (\%) & ND & ND & $7.65 \pm 0.01$ & $4.28 \pm 0.25$ \\
\hline Nonfat solids (\%) & ND & ND & $9.72 \pm 0.01$ & $8.32 \pm 1.39$ \\
\hline Ash (\%) & $1.9 \pm 0.02$ & $1.81 \pm 0.02$ & $0.46 \pm 0.01$ & $0.79 \pm 0.01$ \\
\hline Total solids (\%) & $49.59 \pm 1.02$ & $43.99 \pm 1.07$ & $20.72 \pm 0.03$ & $13.87 \pm 0.53$ \\
\hline Moisture (\%) & $50.41 \pm 0.98$ & $56.01 \pm 0.98$ & $79.98 \pm 0.03$ & $86.16 \pm 0.55$ \\
\hline
\end{tabular}

2.2.5. Cheese Yield. Cheese yield was calculated after maturation according to [14]

$$
\text { Cheese Yield }=\frac{\text { Cheese Weight }(\mathrm{Kg})}{\text { Milk Weight }(\mathrm{Kg})} \times 100 \text {. }
$$

2.2.6. Rheological Analysis. Dynamic oscillatory measurements were performed with an AR 1000 rheometer (TA Instruments, Leatherhead, Surrey, UK). Storage modulus $\left(G^{\prime}\right)$ and loss modulus $\left(G^{\prime \prime}\right)$ were selected as parameters for characterizing the rheological properties of the spreadable cheeses. Rheological measurements were evaluated for duplicate samples after maturation and at the end of shelf life. Samples were carefully placed on the plate using a plastic spoon. $25 \mathrm{~mm}$ stainless steel parallel plate geometry with gap size of $1 \mathrm{~mm}$ was used. All experiments were performed at a constant temperature of $25^{\circ} \mathrm{C}$ with a Peltier plate employed to control temperature $[15,16]$.

2.2.7. Sensory Analysis. Sensory evaluation was carried out by acceptance test by consumers [17]. Cheeses were evaluated after maturation and at the end of shelf life by thirty regular consumers of goat products (nontrained panel). Panel members evaluated cheese for visual appearance, odor, spreadability, taste, texture, and general acceptance using a five-point hedonic scale, with 1 being the worst and 5 the best quality.

2.2.8. Shelf Life. According to actual legislation [18] and previous studies, shelf life of spreadable goat cheese was established in 5 weeks since the elaboration date.

2.2.9. Statistical Analysis. Analysis of variance (ANOVA) was carried out using STATISTICA software (statistical packet Release 6.0 by Statsoft, Inc. 2001, Tulsa, USA).

Data are expressed as the means \pm standard deviation of values obtained from duplicates of the same experiment. The Duncan multiple range test (DMRT) was used to determine the differences among data means at a 5\% significance level.

\section{Results and Discussion}

3.1. Chemical Composition. The only operating variable that significantly affected $(P<0.05)$ chemical composition was pasteurization temperature.

The mean values for the chemical characteristics of spreadable cheese produced, whey obtained, and milk used for elaboration are shown in Table 1.

Cheese elaborated from milk pasteurized at $75^{\circ} \mathrm{C}$ presented higher moisture content, probably due to the presence of whey proteins and their hydrophilic property (Section 3.3.1) $[19,20]$. This characteristic affects the rest of the parameters evaluated, since a higher content of whey increases also cheese yield and enzymatic activity [20]; this enzymatic activity influences positively sensory analysis (Section 3.4). The decrease in levels of protein and fat with pasteurization temperature is due to concomitant increase in moisture and hence the reductions in level of cheese dry matter.

Cheese composition is shown in Table 1; the fat and protein content found in the present study is similar to those reported for other authors for this variety of cheese [21]. According to CAA (art. 605) spreadable goat cheese can be classified as fatty (in dry basis) and very high moisture.

The chemical characteristics of the spreadable goat cheese were analyzed at the end of maturation and shelf life; there were no significant differences $(P>0.05)$ in the parameters between the cheeses at different times. The high values of standard deviation found in fat reflect the variations in this component found in milk used for the elaboration [22].

3.2. $p H$ Determination. $\mathrm{pH}$ of the spreadable goat cheese was determined at the end of maturation and shelf life.

Cheeses made with commercial starter culture had significantly $(P<0.05)$ lower $\mathrm{pH}$ compared to the cheeses made with autochthonous culture

(Table 2).

Figure 1 shows the effect of different starters on $\mathrm{pH}$ development during milk coagulation. The rate of $\mathrm{pH}$ decrease was higher in cheeses made from bovine commercial starter, reaching the desired $\mathrm{pH}$ at 3 hours of process, whereas cheeses from autochthonous starter after $4 \mathrm{~h}$. The high rate 
TABLE 2: Processing conditions on spreadable goat cheeses $\mathrm{pH}$ values.

\begin{tabular}{|c|c|c|c|}
\hline \multicolumn{2}{|c|}{ Processing conditions } & $\mathrm{pH}$ after maturation & $\mathrm{pH}$ after shelf life \\
\hline \multirow{2}{*}{ Pasteurization temperature } & $65^{\circ} \mathrm{C}$ & $5.25 \pm 0.22^{\mathrm{a}}$ & $4.47 \pm 0.20^{\mathrm{a}}$ \\
\hline & $75^{\circ} \mathrm{C}$ & $5.30 \pm 0.30^{\mathrm{a}}$ & $4.51 \pm 0.30^{\mathrm{a}}$ \\
\hline \multirow{2}{*}{ Starter culture } & Autochthonous & $5.30 \pm 0.29^{\mathrm{a}}$ & $4.51 \pm 0.30^{\mathrm{a}}$ \\
\hline & Commercial & $4.36 \pm 0.17^{\mathrm{b}}$ & $3.31 \pm 0.15^{\mathrm{b}}$ \\
\hline \multirow{2}{*}{ Incubation temperature } & $37^{\circ} \mathrm{C}$ & $5.30 \pm 0.29^{\mathrm{a}}$ & $4.51 \pm 0.30^{\mathrm{a}}$ \\
\hline & $42^{\circ} \mathrm{C}$ & $5.27 \pm 0.31^{\mathrm{a}}$ & $4.49 \pm 0.29^{\mathrm{a}}$ \\
\hline
\end{tabular}

Means in each column having different superscripts are significantly different $(P<0.05)$.

TABLE 3: Cheese yield and moisture content of spreadable goat cheese as affected by different processing conditions.

\begin{tabular}{lccr}
\hline \multicolumn{1}{c}{ Processing conditions } & & Moisture (\%) & Yield (\%) \\
\hline \multirow{2}{*}{ Pasteurization temperature } & $65^{\circ} \mathrm{C}$ & $50.41 \pm 0.98^{\mathrm{a}}$ & $23.36 \pm 1.87^{\mathrm{a}}$ \\
& $75^{\circ} \mathrm{C}$ & $56.01 \pm 1.08^{\mathrm{b}}$ & $32.40 \pm 1.64^{\mathrm{b}}$ \\
Starter culture & Autochthonous & $56.01 \pm 0.98^{\mathrm{a}}$ & $32.40 \pm 1.64^{\mathrm{a}}$ \\
& Commercial & $55.89 \pm 1.12^{\mathrm{a}}$ & $32.35 \pm 1.02^{\mathrm{a}}$ \\
Incubation temperature & $37^{\circ} \mathrm{C}$ & $55.88 \pm 1.09^{\mathrm{a}}$ & $32.40 \pm 1.64^{\mathrm{a}}$ \\
& $42^{\circ} \mathrm{C}$ & $48.97 \pm 1.23^{\mathrm{b}}$ & $23.20 \pm 1.21^{\mathrm{b}}$ \\
\hline
\end{tabular}

Means in each column having different superscripts are significantly different $(P<0.05)$.

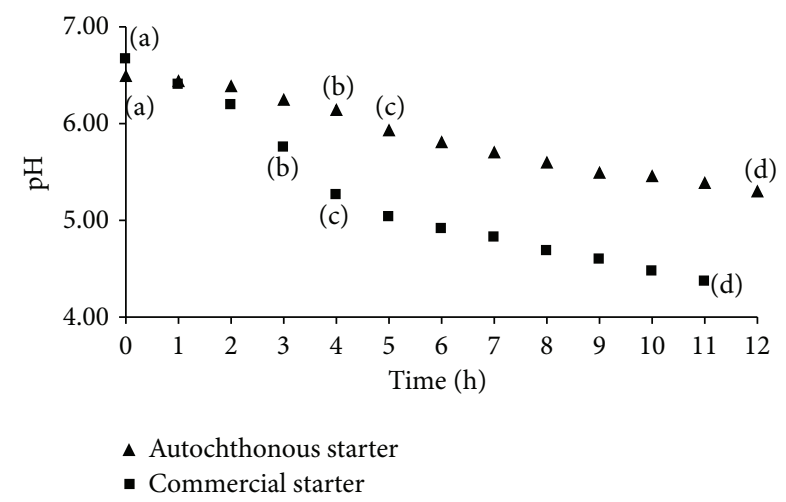

FIGURE 1: pH changes during spreadable goat cheese elaboration for BOTH starters: (a) inoculation; (b) rennet addition; (c) cut and draining; (d) end of draining.

of acidification is not required for this variety due spreadable cheese production involves slow acidification of the curd culture [23]. High rate of acidification causes an acid cheese with tendency growth of fungi and yeasts $[22,23]$.

It should be noted that $\mathrm{pH}$ of cheeses did not remain constant after maturation (autochthonous, 5.30; commercial, 4.36) and storage (autochthonous, 4.51; commercial, 3.31). This indicates that the activity of neither starter culture used was inhibited by the low $\mathrm{pH}$ achieved.

3.3. Cheese Yield. Operating variables that significantly affect $(P<0.05)$ cheese yield were pasteurization and incubation temperature. The mean values for cheese yield and moisture content are shown in Table 3.
3.3.1. Effect of Pasteurization Temperature. The pasteurization temperature had strong positive effect on cheese yield. Cheeses made from pasteurized milk to $75^{\circ} \mathrm{C}$ had higher moisture content, probably due to the presence of whey proteins, since their hydrophilic property allowed higher moisture retention [20]. Upon heating milk above $65^{\circ} \mathrm{C}$, whey proteins are denatured by the unfolding of their polypeptides, thus exposing the side chain groups originally buried within the native structure. The unfolded proteins then interact with casein micelles or simply aggregate with themselves, involving thiol-disulphide interchange reactions, hydrophobic interactions, and ionic linkages [4]. The spreadable cheese structure is similar to yogurt; because of this, the effect of high temperature pasteurization on whey proteins is desirable since heat treatment of the milk considerably enhances firmness. The deposition of denatured serum proteins increases the volume fraction of aggregating protein; it also may alter the number and the nature of the bonds between protein particles [24].

3.3.2. Effect of Incubation Temperature. The incubation temperature significantly affected $(P<0.05)$ cheese yield. Other authors have reported that increased incubation temperature during acidification causes the onset of gelation at higher $\mathrm{pH}$ values, obtaining a thicker gel more susceptible to spontaneous syneresis during storage [1]. This effect may be attributed to a higher ratio of aggregation to disaggregating forces during the earlier stages of acidification owing to decreased casein dissociation from the micelles, a reduction in repulsive forces due to increased hydrophobicity, and faster rate of acidification $[1,25]$. 

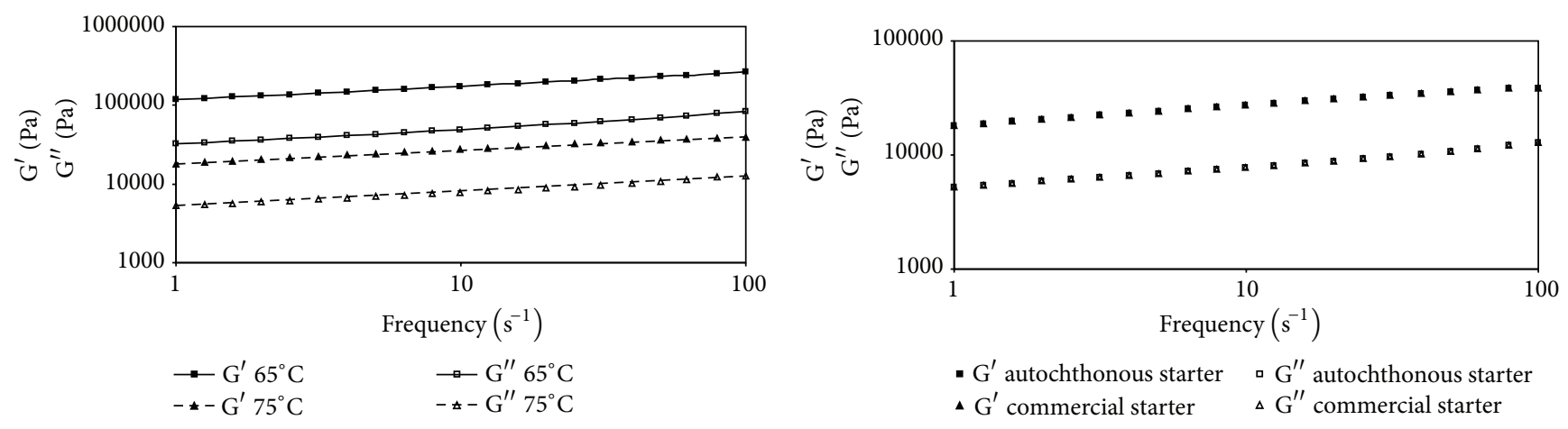

(a)

(b)

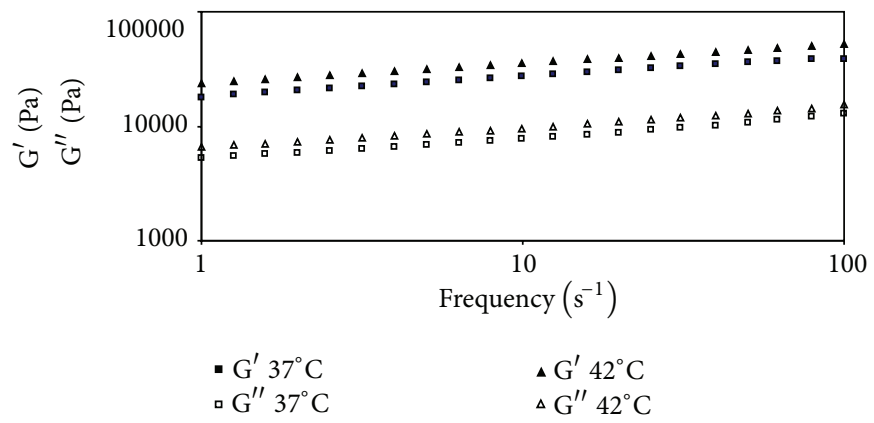

(c)

FIGURE 2: Frequency dependence of $G^{\prime}$ and $G^{\prime \prime}$ for spreadable goat cheeses samples affected by (a) pasteurization temperature; (b) culture; (c) fermentation temperature.

The average cheese yield for samples elaborated from milk pasteurized at $75^{\circ} \mathrm{C}$ and using autochthonous goat culture was $32.4 \%$ (3.24 L milk/Kg cheese). This value exceeds by $40-50 \%$ reported in the literature (5-7.5 L milk/Kg cheese) [26].

3.4. Rheological Measurement. The only operating variable that significantly affected $(P<0.05)$ rheological characteristics was pasteurization temperature. Increasing milk pasteurization temperature significantly decreased the mean values for critical stress.

The stress sweep carried out on the samples pasteurized at 65 and $75^{\circ} \mathrm{C}$ indicates that both have a critical stress value: $65^{\circ} \mathrm{C}, 2508.7 \mathrm{~Pa} ; 75^{\circ} \mathrm{C}, 1363.1 \mathrm{~Pa}$. Applying a small stress («critical stress) on the gel provokes a reversible stretching of the threads making up the cheese matrix; however, if the stress applied is higher than the critical stress, the threads break [16].

Cheeses elaborated from milk pasteurized at $65^{\circ} \mathrm{C}$ show higher $(P<0.05)$ critical stress value than $75^{\circ} \mathrm{C}$ samples; this behavior can be explained by the significant changes occurring upon heating milk above $65^{\circ} \mathrm{C}$ that include the denaturation of whey proteins and the increase of moisture; these effects reduced strength of rennet gels $[3,4]$. This trend, which concurs with previous studies [27], was expected because of the increase in moisture content and reduction in protein percentage as the pasteurization temperature was increased $[28,29]$.
The other factor contributing to reduction of critical stress with pasteurization temperature is the increase in the level of denatured whey proteins, as a percentage of total protein in the cheese. These proteins that are complexed with the casein micelles during heating reduce the degree of casein aggregation during subsequent rennet coagulation and curd formation and lead to a finer gel matrix structure [29-31].

The rheological behavior of spreadable goat cheese as a function of frequency is presented in Figure 2. Cheeses elaborated under different processing conditions ((A) pasteurization temperature, (B) starter culture, and (C) fermentation temperature) exhibited similar characteristics, typical of a weak viscoelastic gel, with storage modulus $\left(G^{\prime}\right)$ greater than loss modulus $\left(G^{\prime \prime}\right)$, and all samples showed some frequency dependence. $\left(G^{\prime}\right)$ and $\left(G^{\prime \prime}\right)$ moduli increased with the increase of frequency; this was also noted by other authors $[8,16]$.

The rise of $G^{\prime}$ with frequency might be due to casein particles fusion as a consequence of the rearrangement of inter- and intramolecular forces, which in turn results in an increased contacting surface between the casein aggregates and possibly to the additional particles added to the web [16].

Under all processing conditions, the elastic component contributes viscoelasticity more than viscous component $\left(G^{\prime}>G^{\prime \prime}\right)$ which leads to a structure resembling more of a solid within the range of frequencies studied, which was also noted by other authors $[16,32,33]$.

Increasing milk pasteurization temperature significantly decreased $(P<0.05)$ the mean values for $\mathrm{G}^{\prime}$ and $\mathrm{G}^{\prime \prime}$ 
TABLE 4: Effects of pasteurization temperature and starter culture on the sensory properties of spreadable goat cheese.

\begin{tabular}{|c|c|c|c|c|c|c|}
\hline \multirow{3}{*}{ Sensory properties } & \multicolumn{6}{|c|}{ Processing conditions } \\
\hline & \multicolumn{2}{|c|}{ Pasteurization temperature } & \multicolumn{2}{|c|}{ Starter culture } & \multicolumn{2}{|c|}{ Incubation temperature } \\
\hline & $65^{\circ} \mathrm{C}$ & $75^{\circ} \mathrm{C}$ & Autochthonous & Commercial & $37^{\circ} \mathrm{C}$ & $42^{\circ} \mathrm{C}$ \\
\hline Visual appearance & $3.05 \pm 0.41^{\mathrm{a}}$ & $4.79 \pm 0.32^{\mathrm{b}}$ & $4.80 \pm 0.29^{\mathrm{a}}$ & $4.82 \pm 0.29^{\mathrm{a}}$ & $4.80 \pm 0.29^{\mathrm{a}}$ & $4.75 \pm 0.27^{\mathrm{a}}$ \\
\hline Odor & $4.52 \pm 0.38^{\mathrm{a}}$ & $4.80 \pm 0.32^{\mathrm{a}}$ & $4.83 \pm 0.35^{\mathrm{a}}$ & $3.21 \pm 0.28^{\mathrm{b}}$ & $4.84 \pm 0.32^{\mathrm{a}}$ & $4.83 \pm 0.35^{\mathrm{a}}$ \\
\hline Spreadability & $2.28 \pm 0.14^{\mathrm{a}}$ & $4.61 \pm 0.25^{\mathrm{b}}$ & $4.59 \pm 0.23^{\mathrm{a}}$ & $4.61 \pm 0.26^{\mathrm{a}}$ & $4.59 \pm 0.23^{\mathrm{a}}$ & $4.23 \pm 0.23^{\mathrm{a}}$ \\
\hline Taste & $4.65 \pm 0.38^{\mathrm{a}}$ & $4.81 \pm 0.32^{\mathrm{a}}$ & $4.81 \pm 0.32^{\mathrm{a}}$ & $2.00 \pm 0.32^{\mathrm{b}}$ & $4.81 \pm 0.32^{\mathrm{a}}$ & $4.80 \pm 0.32^{\mathrm{a}}$ \\
\hline Texture & $2.87 \pm 0.33^{\mathrm{a}}$ & $4.77 \pm 0.27^{\mathrm{b}}$ & $4.78 \pm 0.27^{\mathrm{a}}$ & $4.82 \pm 0.31^{\mathrm{a}}$ & $4.78 \pm 0.26^{\mathrm{a}}$ & $4.73 \pm 0.24^{\mathrm{a}}$ \\
\hline General acceptance & $3.21 \pm 0.25^{\mathrm{a}}$ & $4.79 \pm 0.28^{\mathrm{a}}$ & $4.80 \pm 0.26^{\mathrm{a}}$ & $2.50 \pm 0.32^{\mathrm{b}}$ & $4.80 \pm 0.25^{\mathrm{a}}$ & $4.77 \pm 0.26^{\mathrm{a}}$ \\
\hline Total score & $20.58 \pm 1.21$ & $28.57 \pm 1.17$ & $28.61 \pm 1.22$ & $21.96 \pm 1.19$ & $28.62 \pm 1.22$ & $28.11 \pm 1.24$ \\
\hline
\end{tabular}

Values are means of shelf life time; different superscript letters after values indicate significant differences; Duncan's multiple range test $(P<0.05)$.

(Figure 2(a)); this trend was expected because of the increase in moisture content and in level of denatured whey protein (as explained in stress sweep). The strands of the matrices in cheeses from higher pasteurization temperature milks may be less capable of bearing stress than those in cheese made from milk pasteurized at $65^{\circ} \mathrm{C}$ [29]; this is related with the lowest critical stress found in cheese elaborated from milk pasteurized at $75^{\circ} \mathrm{C}$. The rheological results agree with the macroscopic appearance of experimental cheeses (Figures 3 and 4). Cheese elaborated from milk pasteurized at $65^{\circ} \mathrm{C}$ did not show the soft texture and spreadability expected, unlike the cheeses elaborated from milk pasteurized at $75^{\circ} \mathrm{C}$.

No significant difference $(P>0.05)$ was noticed in $G^{\prime}$ and $G^{\prime \prime}$ values among spreadable cheeses samples made from autochthonous or commercial starter (Figure 2(b)). This result is positive for the study, since the principal sensorial attributes of the cheese elaborated with commercial starter culture were spreadability and texture; therefore similar rheological characteristics were desired in cheese elaborated with autochthonous starter culture. These results agree with sensory characteristics (Section 3.4).

$G^{\prime}$ and $G^{\prime \prime}$ values increased gradually with fermentation temperature, but no significant difference $(P>0.05)$ was noticed among spreadable cheeses samples (Figure 2(c)). Other authors have reported significant differences employing incubation temperatures between 20 and $28^{\circ} \mathrm{C}$ [8].

The rheological behavior of the spreadable goat cheese was analyzed at the end of maturation and shelf life; there were no significant differences $(P>0.05)$ in the parameters.

3.5. Sensory Characteristics. Sensory characteristics were evaluated after maturation and at the end of shelf life and there was no significant difference $(P<0.05)$. Operating variables that significantly affect $(P<0.05)$ sensory characteristics were pasteurization temperature and starter culture.

3.5.1. Effect of Pasteurization Temperature. Pasteurization temperature affected significantly $(P<0.05)$ texture, spreadability, and visual appearance (Table 4 ). This finding may be attributed to the effect of the pasteurization temperature on water-holding capacity (Figures 3 and 4).

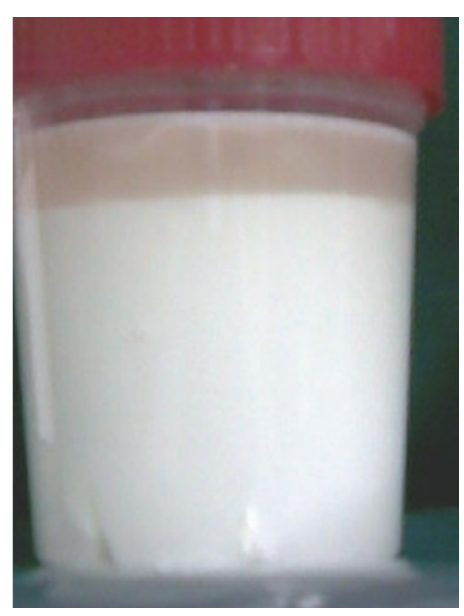

FIGURE 3: Cheese made from milk pasteurized at $65^{\circ} \mathrm{C}$.

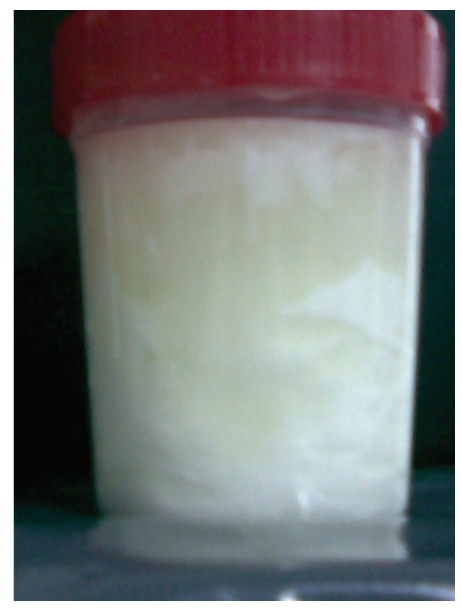

FIGURE 4: Cheese made from milk pasteurized at $75^{\circ} \mathrm{C}$.

Samples pasteurized at $75^{\circ} \mathrm{C}$ had higher scores in visual appearance, spreadability, and texture; this is agreed with rheological results.

3.5.2. Effect of Starter Culture. The spreadable cheese made from autochthonous starter received higher scores in the 


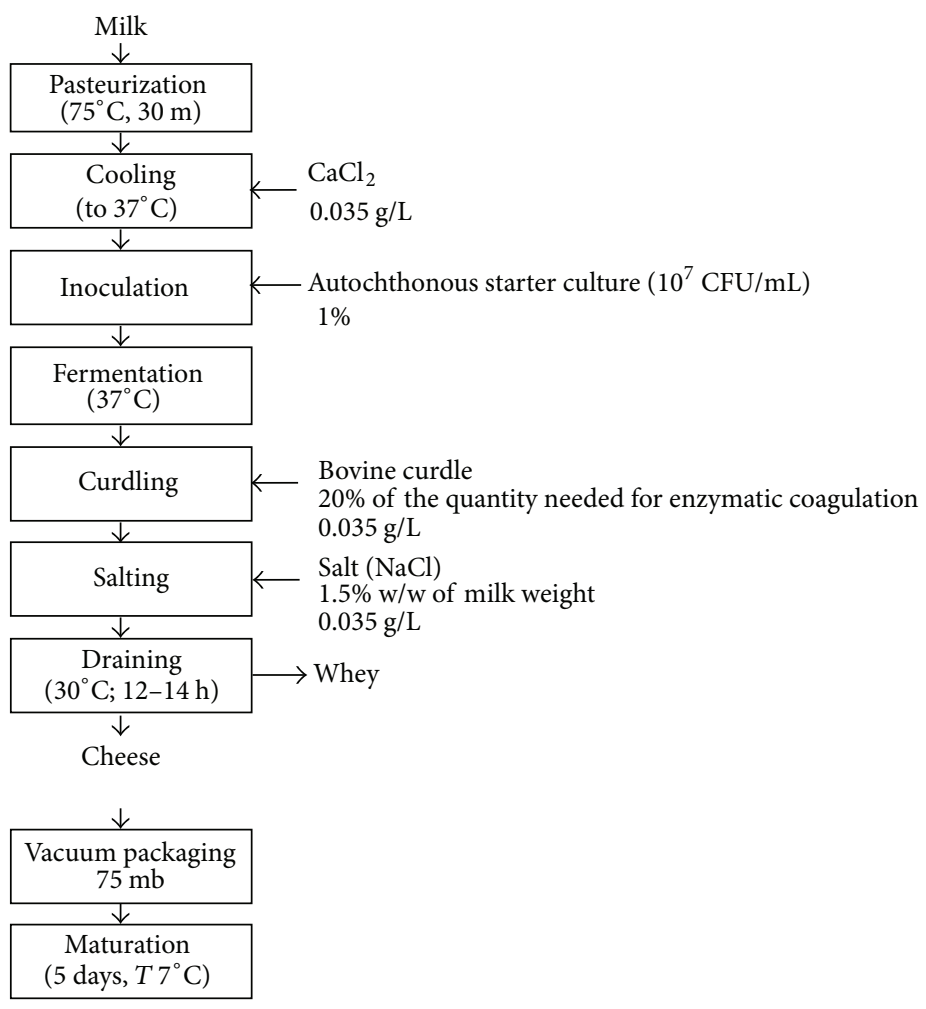

FIgURE 5: : Spreadable goat cheese elaboration process.

sensory evaluation than cheese made using commercial starter. The starter culture had a statistically significant effect $(P<0.05)$ on odor, taste, and general acceptance (Table 4$)$; these samples had an intense and typical goat flavor attributes that consumers expect to find in goat products and a slightly acidic taste. Similarly, other authors have reported aroma intensity to be higher in cheeses made with an autochthonous culture $[6,34,35]$. Commercial starter batch had the lowest scores in taste, odor, and general acceptance due its highly acidic taste and the absence of characteristic goat flavor.

There was no significant difference $(P>0.05)$ in visual appearance, spreadability, texture, or general acceptance between different starter culture. These were the expected outcomes due to the fact that cheeses elaborated with bovine commercial culture present textural properties suitable for this cheese variety.

After the study of the specific processing conditions (pasteurization temperature, starter culture, and incubation temperature), the optimal process for spreadable goat cheese elaboration was defined; this result is diagrammed in Figure 5.

\section{Conclusion}

An attempt was made to assess the impact of pasteurization temperature, starter culture, and incubation temperature on spreadable goat cheese. The results indicated that pasteurization at $75^{\circ} \mathrm{C}$ for 30 minutes has a positive impact on cheese yield, rheological properties, and sensory analysis.
Cheeses made with autochthonous starter culture showed better sensory characteristics and higher $\mathrm{pH}$ compared to the cheeses made with commercial culture; therefore the use of the selected autochthonous starter could be an interesting way to produce on an industrial scale, a uniform product of constant quality with improved sensory characteristics. By lowering the incubation temperature to $37^{\circ} \mathrm{C}$ was able to improve cheese yield.

\section{Conflict of Interests}

The authors declare that there is no conflict of interests regarding the publication of this paper.

\section{References}

[1] T. P. Guinee, P. Pudja, and N. Farkye, "Fresh acid-curd cheese varieties," in Cheese: Chemistry, Physics and Microbiology, Aspen, Gaithersburg, Md, USA, 1999.

[2] F. Frau, Desarrollo de quesos untables de cabra usando fermentos lácticos autóctonos, como estrategia tecnológica para la cuenca caprina de Santiago del Estero [Ph.D. thesis], Facultad de Agronomía y Agroindustrias, Santiago del Estero, Argentina, 2011.

[3] D. G. Dalgleish, "Denaturation and aggregation of serum proteins and caseins in heated milk," Journal of Agricultural and Food Chemistry, vol. 38, no. 11, pp. 1995-1999, 1990.

[4] H. Singh and A. Waungana, "Influence of heat treatment of milk on cheesemaking properties," International Dairy Journal, vol. 11, no. 4-7, pp. 543-551, 2001. 
[5] M. Broome, "Adjunct culture metabolism and cheese flavour," in Improving the Flavour of Cheese, B. C. Weimer, Ed., CRC Press, Washington, DC, USA, 2007.

[6] L. González and V. Zárate, "Influence of an autochthonous starter culture and a commercial starter on the characteristics of Tenerife pasteurised goats' milk cheese," International Journal of Dairy Technology, vol. 65, no. 4, pp. 542-547, 2012.

[7] H. S. Ramaswamy and S. Basak, "Rheology of stirred yogurts," Journal of Texture Studies, vol. 22, no. 2, pp. 231-241, 2007.

[8] M. Bensmira and B. Jiang, "Effect of some operating variables on the microstructure and physical properties of a novel Kefir formulation," Journal of Food Engineering, vol. 108, no. 4, pp. 579-584, 2012.

[9] J. M. Murray, C. M. Delahunty, and I. A. Baxter, "Descriptive sensory analysis: past, present and future," Food Research International, vol. 34, no. 6, pp. 461-471, 2001.

[10] FIL-IDF 9C:1987, "Determination of fat content," Tech. Rep., International Dairy Federation, Brussels, Belgium, 1987.

[11] C. C. Hach, S. V. Brayton, and A. B. Kopelove, "A powerful Kjeldahl nitrogen method using peroxymonosulfuric acid," Journal of Agricultural and Food Chemistry, vol. 33, no. 6, pp. 1117-1123, 1985.

[12] IDF, "Determination of total solids content," Tech. Rep. FIL-IDF 4A:1982, International Dairy Federation, Brussels, Belgium, 1982.

[13] Association of Official Analytical Chemists-AOAC, Ash in Cheese, vol. 2 of Official Methods of Analysis of International, AOAC, Gaithersburg, Md, USA, 15th edition, 1990.

[14] L. M. Spadoti, J. R. F. Dornellas, A. J. Petenate, and S. M. Roig, "Avaliação do rendimento do queijo tipo prato obtido por modificações no processo tradicional de fabricação," Food Science and Technology (Campinas), vol. 23, no. 3, pp. 492-499, 2003.

[15] P. M. Kelly and B. T. O'Kennedy, "The effect of casein/whey protein ratio and minerals on the rheology of fresh cheese gels using a model system," International Dairy Journal, vol. 11, no. 4-7, pp. 525-532, 2001.

[16] F. Frau, "Rheology of spreadable goat cheese made with autochthonous lactic cultures differing in their ability to produce exopolysaccharides," Food Science and Technology, vol. 33, no. 2, pp. 233-238, 2013.

[17] L. F. J. Pastor, B. M. Mellado, A. A. Ramirez, and R. E. Dolores, "Sensory evaluation of goatmilk cheese type Boursin natural and ash flavor," Revista Electrónica de Veterinaria, vol. 9, no. 8, pp. 1695-7504, 2008.

[18] Código Alimentario Argentino CAA, "Capítulo VII: Alimentos Lácteos," Art 605, http://www.anmat.gov.ar/alimentos/codigoa/CAPITULO_VIII.pdf.

[19] A. Kilara, "Whey protein functionality," in Protein Functionality in Food Systems, N. S. Hettiarachchy and G. R. Ziegler, Eds., CRC Press, New York, NY, USA, 1994.

[20] C. A. Meinardi, C. A. Zalazar, E. R. Hynes, and M. C. Candiotti, "Incremento del rendimeinto del queso cremoso argentino por tratamiento de la leche a temperaturas y tiempos superiores a los de pasteurización," Revista Argentina de Lactología, vol. 22, pp. 45-54, 2003.

[21] P. Peláez-Puerto, Caracterización de los quesos laborados con leche de cabra en la isla de Tenerife: influencia de factores ambientales en el desarrollo de sus características organolépticas y físico-químicas [Ph.D. Thesis], Universidad de la Laguna, Tenerife, Spain, 2003.
[22] F. Frau, G. Font, and N. Pece, “Composición fisicoquímica y calidad microbiológica de leche de cabra producida en la provincia de Santiago del Estero (Argentina)," Archivos Latinoamericanos de Producción Animal, vol. 21, no. 1, pp. 1-13, 2012.

[23] P. Fox, T. Guinee, T. Cogan, and P. McSweeney, Fundamentals of Cheese Science, Aspen Publishers, Gaithersburg, Md, USA, 2000.

[24] P. Walstra, J. T. M. Wouters, and T. J. Geurts, Dairy Science and Technology, CRC Press, Boca Raton, Fla, USA, 2nd edition, 2006.

[25] A. Haque, R. K. Richardson, and E. R. Morris, "Effect of fermentation temperature on the rheology of set and stirred yogurt," Food Hydrocolloids, vol. 15, no. 4-6, pp. 593-602, 2001.

[26] C. Sánchez, M. García, and R. Prays, "Mejoramiento del rendimiento y de las características organolépticas del queso blanco suave y crema elaborado con leche de cabra," Zootecnia Tropical, vol. 12, no. 1, pp. 115-131, 1994.

[27] T. P. Guinee, M. A. Fenelon, E. O. Mulholland, B. T. O’Kennedy, N. O'Brien, and W. J. Reville, "The influence of milk pasteurization temperature and $\mathrm{pH}$ at curd milling on the composition, texture and maturation of reduced fat cheddar cheese," International Journal of Dairy Technology, vol. 51, no. 1, pp. 1-10, 1998.

[28] T. P. Guinee, M. A. E. Auty, and M. A. Fenelon, "The effect of fat content on the rheology, microstructure and heat-induced functional characteristics of Cheddar cheese," International Dairy Journal, vol. 10, no. 4, pp. 277-288, 2000.

[29] N. M. Rynne, T. O. Beresford, A. L. Kelly, and T. P. Guinee, "Effect of milk pasteurization temperature and in situ whey protein denaturation on the composition, texture and heatinduced functionality of half-fat Cheddar cheese," International Dairy Journal, vol. 14, no. 11, pp. 989-1001, 2004.

[30] M. J. Pearse, P. M. Linklater, R. J. Hall, and A. G. Mackinlay, "Effect of heat induced interaction between $\beta$ - lactoglobulin and $\kappa$-casein on syneresis," Journal of Dairy Research, vol. 52, pp. 159-165, 1985.

[31] M. L. Green, "Cheddar cheesemaking from whole milk concentrated by ultrafiltration and heated to $90^{\circ} \mathrm{C}$," Journal of Dairy Research, vol. 57, pp. 559-569, 1990.

[32] W. Messens, D. van de Walle, J. Arevalo, K. Dewettinck, and A. Huyghebaert, "Rheological properties of high-pressure-treated Gouda cheese," International Dairy Journal, vol. 10, no. 5-6, pp. 359-367, 2000.

[33] M. F. San Martín-González, J. J. Rodríguez, S. Gurram, S. Clark, B. G. Swanson, and G. V. Barbosa-Cánovas, "Yield, composition and rheological characteristics of cheddar cheese made with high pressure processed milk," LWT_Food Science and Technology, vol. 40, no. 4, pp. 697-705, 2007.

[34] C. M. Lynch, D. D. Muir, J. M. Banks, P. L. H. McSweeney, and P. F. Fox, "Influence of adjunct cultures of Lactobacillus paracasei ssp. paracasei or Lactobacillus plantarum on Cheddar cheese ripening," Journal of Dairy Science, vol. 82, no. 8, pp. 1618-1628, 1999.

[35] M. Ortigosa, C. Arizcun, P. Torre, and J. M. Izco, "Use of wild Lactobacillus strains in an adjunct culture for a Roncal-type cheese," Journal of Dairy Research, vol. 72, no. 2, pp. 168-178, 2005. 

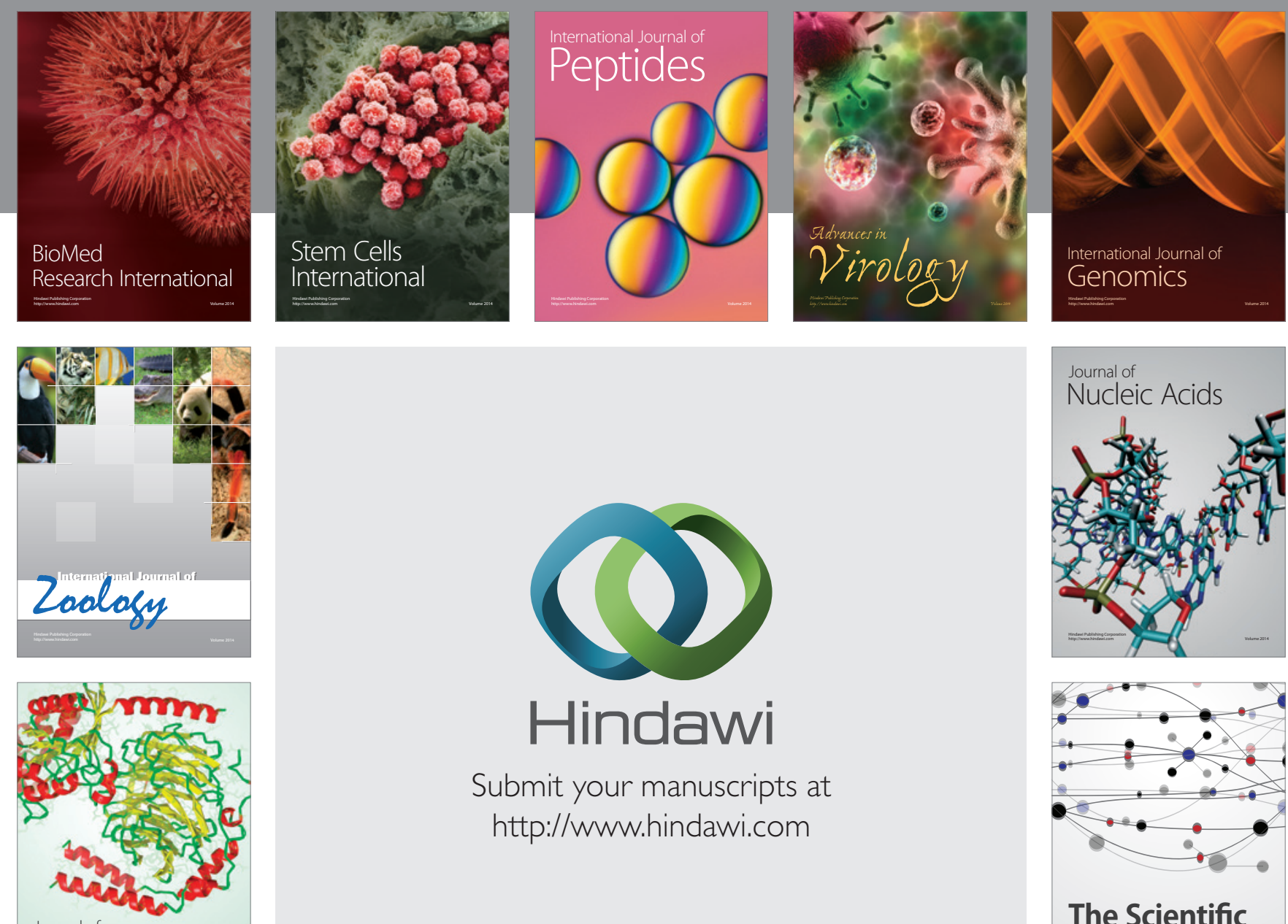

Submit your manuscripts at

http://www.hindawi.com

Journal of
Signal Transduction
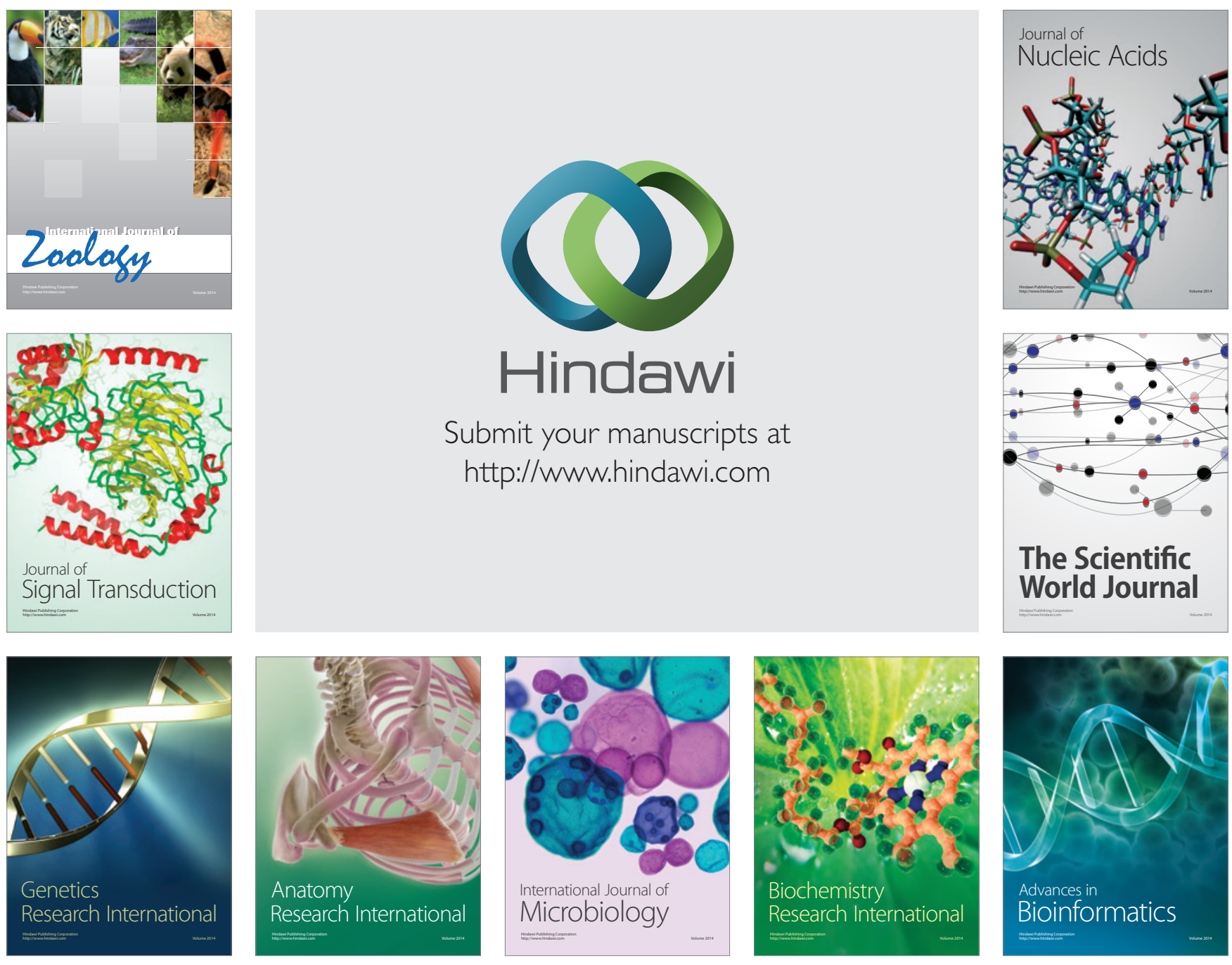

The Scientific World Journal
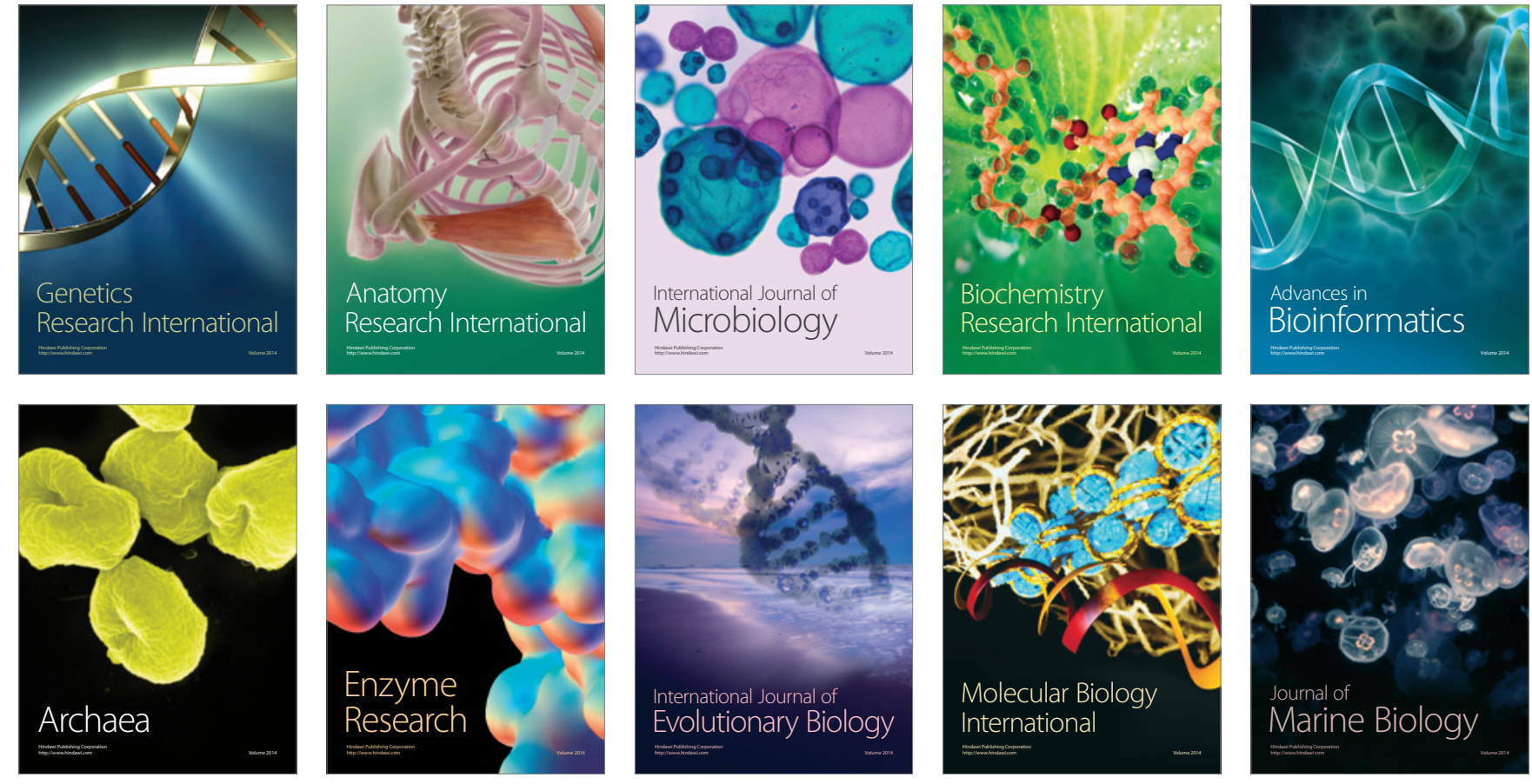